\title{
Role of deep-sea bacteria in organic matter mineralization and adaptation to hydrostatic pressure conditions in the NW Mediterranean Sea
}

\author{
Christian Tamburini* ${ }^{*}$ Jean Garcin, Armand Bianchi \\ Laboratoire de Microbiologie Marine, CNRS-INSU, UMR 6117, Université de la Méditerranée, Centre d'Océanologie de \\ Marseille, Campus de Luminy, Case 907, 13288 Marseille Cedex 9, France
}

\begin{abstract}
Ectoaminopeptidase activity (EAA), ${ }^{14} \mathrm{C}$-glutamic acid assimilation (GA) and respiration (GR) rates were measured over spring and fall, whilst maintaining in situ hydrostatic pressure condition through a $2000 \mathrm{~m}$ water column in the NW Mediterranean. Depth-integrated EAA was maximal in the deep-sea layer due to the lack of ready-to-use compounds. Conversely, depth-integrated fluxes for GA and GR in the bathypelagic zone, though far from negligible, were much lower than in the photic layer, the exception being in the 1000 to 2000 m layer during fall when respiration fluxes and particle fluxes were optimal. Metabolic rates obtained from samples recovered and incubated under in situ pressure conditions were $4.53 \pm 4.45$ (mean $\pm \mathrm{SD}_{;} \mathrm{n}=19$ ) times higher than their decompressed counterparts, proving that deep-sea bacteria were adapted to high pressure. ${ }^{14} \mathrm{C}$-glutamic acid uptake rates $(\mathrm{GU}=\mathrm{GA}+\mathrm{GR})$ measured under in situ pressure conditions were used to calculate the bacterial ${ }^{14} \mathrm{C}$-glutamic acid assimilation yield $\left(\mathrm{GY}_{\mathrm{G}}=\mathrm{GA} / \mathrm{GU}\right)$. In decompressed samples this yield was always lower by around $20 \%$ than in those measured under in situ pressure conditions. Because experiments currently used to estimate bacterial growth efficiency (BGE) are not carried out under in situ pressure conditions, we hypothesize that pressure affects BGE in the same way that it affects $\mathrm{GY}_{\mathrm{G}}$. Thus, the stress caused by decompression induces an increase in energy cost, and so underestimates BGE. Growth of deep-sea bacteria is highly dependent on the quantity and quality of sinking particles reaching $1000 \mathrm{~m}$. During mesotrophic conditions (spring), high fluxes of relatively fresh particulate organic carbon generated relatively small depth-integrated EAA rates $\left(20.6 \mathrm{mg} \mathrm{C} \mathrm{m}^{-2} \mathrm{~h}^{-1}\right)$ and high $\mathrm{GY}_{\mathrm{G}}(65 \%)$. Meanwhile, during oligotrophic conditions (fall), a minimal flux of old organic matter generated maximal depth-integrated EAA rates $\left(62.2 \mathrm{mgC} \mathrm{m}^{-2} \mathrm{~h}^{-1}\right)$ and lower $\mathrm{GY}_{\mathrm{G}}(12 \%)$. From these observations and from the literature, we explore the relationship between the nutritive sources available to deep-sea bacteria, their role in the mineralization of peptide compounds and consequently the implications for the global carbon cycle.
\end{abstract}

KEY WORDS: Deep sea - Bacteria - Organic matter - Mineralization - Peptidase activity - BGE · Bacterial growth efficiency $\cdot$ Mediterranean Sea

Resale or republication not permitted without written consent of the publisher

\section{INTRODUCTION}

Around $50 \%$ of the organic carbon produced daily by photosynthetic organisms in the euphotic zone is processed by bacteria and used to produce new bacterial biomass and satisfy the energy requirements for bacterial respiration (Ducklow \& Carlson 1992). Deeper in the water column, bacteria consume between 40 and $100 \%$ of the sinking fluxes of particu- late organic carbon (POC). This indicates that there is a tight coupling between sinking particles and freeliving bacteria in the mesopelagic (Cho \& Azam 1988, Smith et al. 1992) and bathypelagic layers (Nagata et al. 2000).

Bacterial activity rates measured in the deep-water layer of the ocean appear low relative to those described in the surface layer. However, when the measured rates are integrated through the depth of each 
water layer, the mineralization fluxes mediated by prokaryotic populations at depths more than $200 \mathrm{~m}$ appear far from negligible (Lefèvre et al. 1996, del Giorgio et al. 1997, Bianchi et al. 1998, Tamburini et al. 2002).

Most of the organic compounds produced in natural waters have a polymeric structure. Such high molecular weight (HMW) biopolymers must be transformed into low molecular weight (LMW) compounds by ectoenzymatic processes. This is because only LMW compounds $(<600 \mathrm{Da})$ are able to enter into the cell (Nikaido \& Vaara 1985, Chrost 1991, Chrost \& Velimirov 1991) to produce bacterial biomass and energyyielding reactions that ultimately lead to carbon dioxide production. These ectoenzymatic activities are considered to be the limiting step for the heterotrophic mineralization of organic matter (Chrost 1991).

The DYFAMED time-series station, which is devoid of horizontal advection currents (Andersen \& Prieur 2000), is an interesting zone for studying the mineralization fluxes generated by the prokaryotic compartment through the water column from the sea surface down to $2300 \mathrm{~m}$. Moreover, this water column is relatively homoeothermic $\left(13^{\circ} \mathrm{C}\right.$ from the subsurface to the bottom), enabling us to focus on the effects of increasing hydrostatic pressure on microbial activity, independently from the effects of decreasing temperature, which is usually encountered in deep-sea waters. It is now well accepted that high-pressure conditions affect the metabolism of marine bacteria (ZoBell \& Oppenheimer 1950, Deming et al. 1980, Tabor et al. 1981, Jaenicke 1987, Straube et al. 1990, Turley \& Lochte 1990, Poremba 1994, Yayanos 1995). In previous studies, we demonstrated that changes in hydrostatic pressure during sampling affect the uptake rate of LMW compounds by deep-sea bacteria (Bianchi \& Garcin 1993, Bianchi \& Garcin 1994, Tholosan et al. 1999). More recently, we have demonstrated that pressure conditions also affect bacterial populations carrying out biopolymer hydrolysis in deep-sea waters (Tamburini et al. 2002).

In the present study, we focus on the coupling between the rates of HMW biopolymer hydrolysis (via aminopeptidase activity) and the uptake rates of LMW amino acids (resulting from the hydrolysis process), through the water column (down to $2300 \mathrm{~m}$ ) in the NW Mediterranean. All the assays were concomitantly performed under in situ and atmospheric pressure conditions. We were therefore able to examine the effects of high hydrostatic pressure on the microbial transformation of single organic compounds, by heterotrophic bacteria, into new bacterial biomass and inorganic $\mathrm{C}$. From the transformation of a single organic substrate we discuss the effects of environmental conditions (depth, season, pressure conditions) on the corre- sponding bacterial growth yield, and its consequent implications on the role of microbes in nutrient cycling.

\section{MATERIALS AND METHODS}

Sampling area and sampling protocol. Sampling was carried out during 2 cruises (in April and September 2000) in the NW Mediterranean, at the DYFAMED times-series station (Fig. 1). This station is located 28 miles SE of Nice $\left(43^{\circ} 25^{\prime} \mathrm{N}, 07^{\circ} 52^{\prime} \mathrm{E}\right)$. Sampling was carried out using a High Pressure Serial Sampler (HPSS, Bianchi et al. 1999), which can be simultaneously fitted with conventional 121 Niskin bottles and $500 \mathrm{ml}$ pressure-retaining bottles (high-pressure bottles, HPB). The labeled compound used to measure metabolic activity is injected, before immersion, into the HPB through the injection port, so it is mixed into the sample volume during filling (Fig. 2). During retrieval and subsequent incubation periods, pressure conditions in each HPB were recorded continuously, via the deck unit of the CTD (Sea-Bird 911 plus). Incubations of HPBs were carried out in a temperaturecontrolled water bath, so that the samples were kept at the in situ temperature. In order to perform timecourse experiments, a series of sub-samples were successively collected without introducing any pressure loss into the culture vessels.

The daily sampling protocol was carried out as follows: during the same hydrocast, 3 samples were collected using Niskin bottles -1 in the surface layer

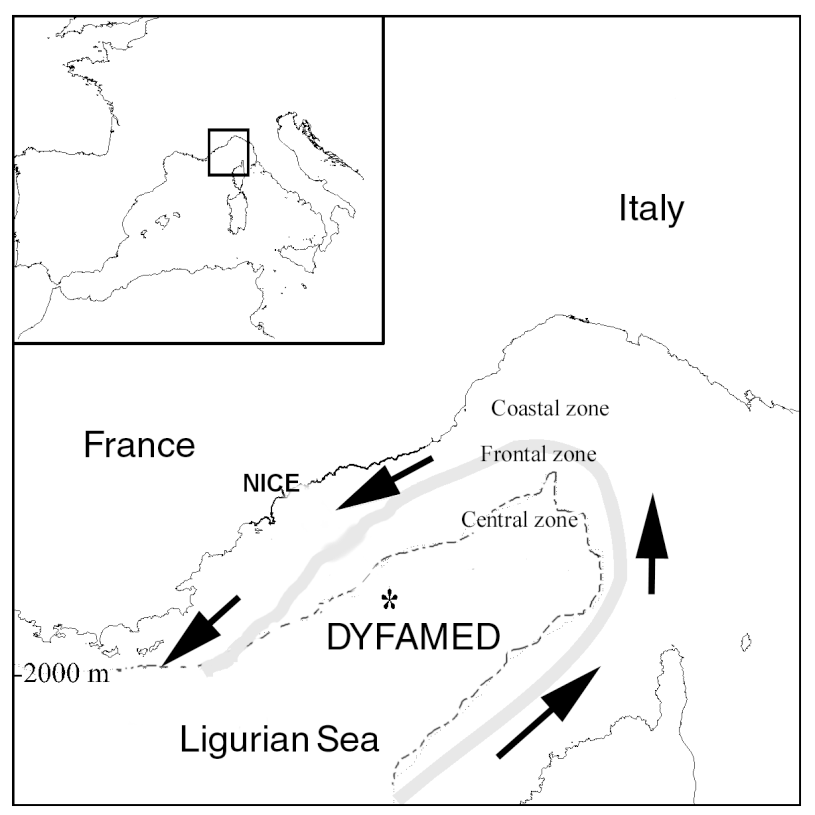

Fig. 1. Location of the DYFAMED time-series station, relative to the Ligurian current (black arows) 


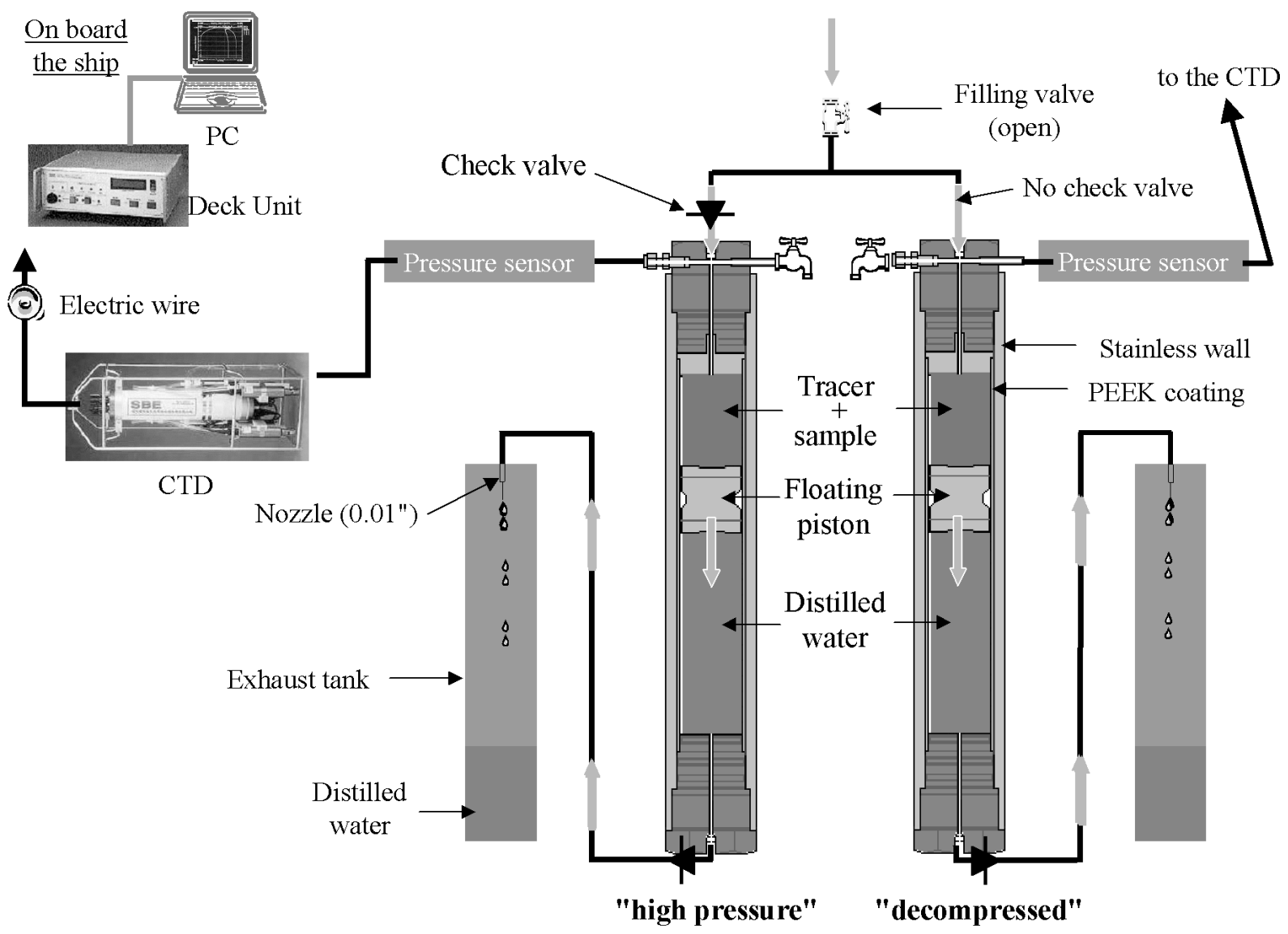

Fig. 2. Diagrammatic representation of the high-pressure bottles (HPBs) in configuration of samples filling. The filling valve is set off by the scientist on board the ship. When the filling valve is opened, the natural hydrostatic pressure pushes down the floating piston and the seawater enters into the upper chamber of 2 HPBs. The distilled water is flushed out from the lower chamber of the syringes to the exhaust tanks, through a nozzle that acts as an hydraulic brake (Bianchi et al. 1999). During retrieval, hydrostatic pressure is maintained thanks to a check valve that avoided any decompression within the 'high pressure' HPBs, in contrast to the 'decompressed' HPBs that had no check valve

(0 to $200 \mathrm{~m}), 1$ in the intermediate layer (200 to $800 \mathrm{~m}$ ), and 1 in the deep-water layer (800 to $2000 \mathrm{~m}$ ). Three duplicates of HPB samples were collected between 800 and $2000 \mathrm{~m}$. Each duplicate included 2 HPBs concomitantly filled through the same filling valve, 1 being maintained at in situ pressure while the second was decompressed during retrieval (Fig. 2). All bacterial activity measurements were processed on board the research vessel, immediately after sample retrieval.

Ectoenzymatic degradation of biopolymers. The fluorogenic substrate L-leucine-7-amino-4-methylcoumarin (Leu-MCA; Sigma Chemical) was used to measure aminopeptidase activity (Hoppe 1993). For each sampling depth, determination of the maximum velocity $\left(\mathrm{V}_{\max }\right)$ was performed using 8 final concentrations $(0.05,0.1,0.25,0.5,1.0,1.5,2.5$ and $5.0 \mu \mathrm{M})$, according to the multi-concentration kinetic method. Incubations were carried out in duplicate in the dark at in situ temperature $\left(13 \pm 1^{\circ} \mathrm{C}\right)$. Enzyme assays were run in time-course experiments over $0,2,4,6$ and $12 \mathrm{~h}$, and the increase in fluorescence was determined using a Kontron SFM 25 spectrofluorometer (emission and excitation wavelengths of 455/365 nm). As we didn't have the $24 \mathrm{HPBs}$ necessary to concomitantly monitor 8 final concentrations at our disposal (each concentration requires 3 HPBs: 2 for duplicates and 1 for boiled blank), the multi-concentration assays were realized using samples collected with a Niskin bottle. The assays allowed us to determine the saturation concentration for each sampling depth. For the experimental assays carried out under ambient pressure conditions using the HPBs, at each sampling depth substrate was added at the saturation concentration defined during the multi-concentration experiments mentioned above. Leu-MCA was used as the model substrate for proteins, so $\mathrm{V}_{\max }$ was expressed in $\mu \mathrm{MC} \mathrm{h}^{-1}$, using a $\mathrm{C}$ per mole ratio of 4.2 (i.e. aver- 
age $\mathrm{C}$ per mole ratio of amino acids) instead of the leucine ratio (6 C per mole leucine) (Lamy et al. 1999).

Uptake of low molecular weight compounds. The most abundant amino acids in the marine DOM pool are glutamic acid, aspartic acid, glycine, serine and alanine (McCarthy et al. 1996, Lee et al. 2000, Amon et al. 2001, Benner 2002). A solution of $\mathrm{L}-\left(\mathrm{U}_{-}{ }^{14} \mathrm{C}\right)$ glutamic acid, specific activity $254 \mathrm{mCi} \mathrm{mmol}^{-1}$ (Amersham), was added to obtain a final concentration of $20 \mathrm{nM}$ (samples collected between 0 and $200 \mathrm{~m}$ ) or $10 \mathrm{nM}$ (samples collected below $200 \mathrm{~m}$ ) ensuring $\mathrm{V}_{\max }$ conditions. Sample processing was as described for the ectoenzymatic measurements. At the end of each incubation period, subsamples were fixed by the addition of buffered formalin (1\% final concentration, v/v). Bacterial cells were collected by gentle vacuum filtration onto $0.2 \mu \mathrm{m}$ polycarbonate filters (Nuclepore ${ }^{\circledR}$ ) pre-washed with unlabeled glutamate solution. Filters were then washed twice with $5 \mathrm{ml}$ of $0.2 \mu \mathrm{m}$ filtered seawater. The filtrate was treated to recover the ${ }^{14} \mathrm{CO}_{2}$ released by acidification (as described by C. Tamburini \& M. A. Tedetti unpubl.). Labeled $\mathrm{C}$ on the filters and in the $\mathrm{CO}_{2}$-traps was counted using a Packard 1600 TR liquid scintillation counter. ${ }^{14} \mathrm{C}$-glutamate assimilation (GA), ${ }^{14} \mathrm{C}$-glutamate respiration (GR) and ${ }^{14} \mathrm{C}$-glutamate utilization $(\mathrm{GU}=$ sum of assimilated and respired label) rates were computed from these time series data. Samples were corrected for blanks, as the time zero was included in the regression.

\section{RESULTS}

\section{Hydrological conditions and depth profile of glutamic acid uptake}

In the DYFAMED area, Béthoux et al. (1988) describe the surface water (down to $200 \mathrm{~m}$ ) as having a seasonally variable temperature; the intermediate water, which is of Levantine origin (LIW) as having high salinity levels ( $\mathrm{S}>38.45)$, high nutrient concentrations, and minimal oxygen concentrations (at depths of 300 to $400 \mathrm{~m}$ ); and the deep water, which is colder and less saline than the LIW. This water mass, the Western Deep Mediterranean Water (WDMW), characterized by stable temperature $\left(12.70^{\circ} \mathrm{C}\right)$ and salinity (38.40) throughout the year, is formed via deep convection in the Gulf of Lions. In surficial waters, production varies with the seasonal hydrological regime, from mesotrophy in spring to oligotrophy in fall (Marty et al. 2002).

Fig. 3 shows that the maximal rates for ${ }^{14} \mathrm{C}$-glutamic acid assimilation and respiration appeared in the subsurface layer irrespective of sampling season. In spring, the $\mathrm{V}_{\max }$ for ${ }^{14} \mathrm{C}$-glutamic acid assimilation (Fig. 3a) was $2580 \mathrm{pgC}^{-1} \mathrm{~h}^{-1}$ at $10 \mathrm{~m}$, decreased 1 order of magnitude at $200 \mathrm{~m}$, and was around $24 \mathrm{pgC}^{-1} \mathrm{~h}^{-1}$ down to $800 \mathrm{~m}$. Respiration rates always surpassed assimilation rates (Fig. 3b). In fall and in spring, the general trend for the depth profiles was quite similar, but in the intermediate and deep-waters $\mathrm{CO}_{2}$ production was greatly enhanced in fall.

\section{(a) Glutamic acid assimilation (pg $\left.\mathrm{Cl}^{-1} \mathrm{~h}^{-1}\right)$}

\section{(b) Glutamic acid respiration ( $\left.\mathrm{pg} \mathrm{CO}_{2} \mathrm{I}^{-1} \mathrm{~h}^{-1}\right)$}

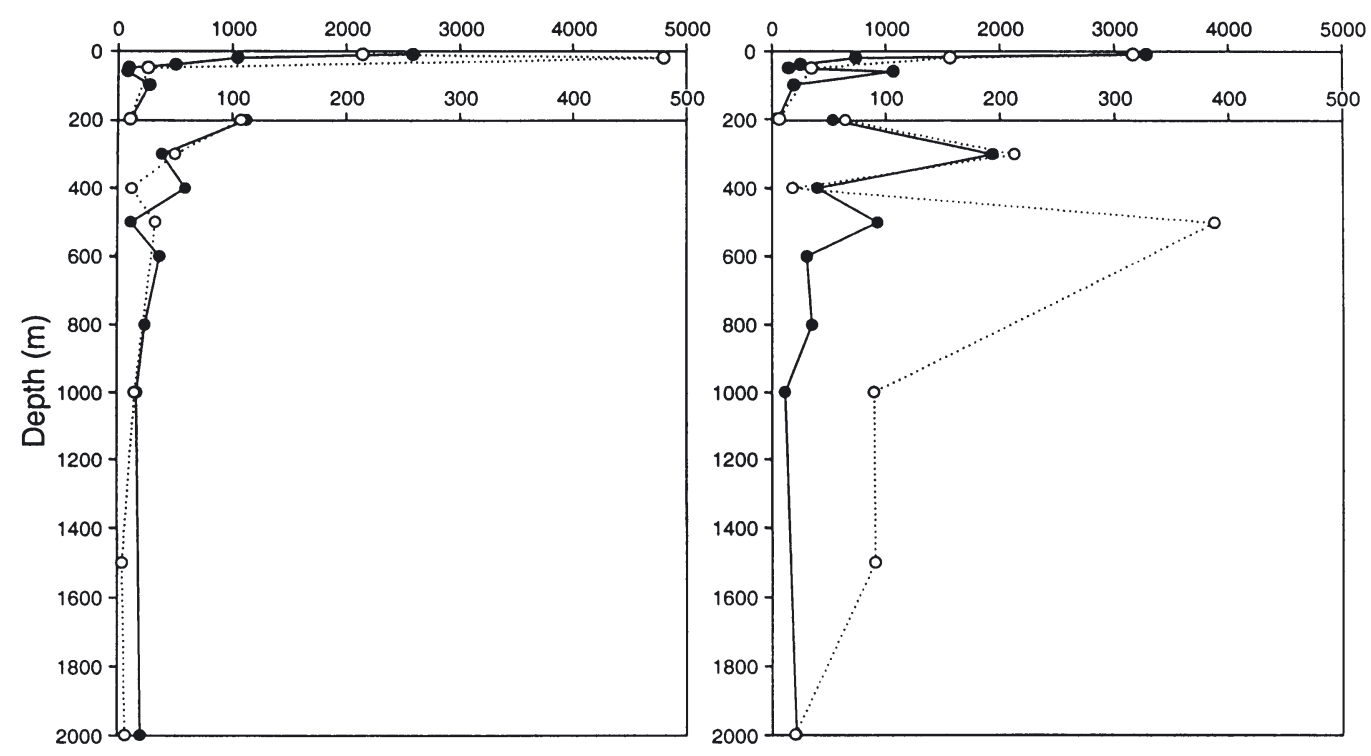

Fig. 3. Depth profiles for (a) potential glutamic acid assimilation and (b) glutamic acid respiration through the water column in spring and fall. (•) Spring, (o) fall. Note different scales for surface waters and deeper layers 


\section{Pressure effect}

Table 1 shows that all the metabolic rates were always higher when measured under ambient pressure conditions $\left(\mathrm{V}_{\mathrm{HP}}\right)$ than in their decompressed counterpart ( $\left.\mathrm{V}_{\mathrm{DEC}}\right)$, in spring as well as in fall. The pressure effect $(\mathrm{Pe}=$ $\left.\mathrm{V}_{\mathrm{HP}} / \mathrm{V}_{\mathrm{DEC}}\right)$ appears highly variable. From the whole Pe data set (Table 1), the average value is equal to $4.5 \pm 4.4$ (mean $\pm \mathrm{SE}, \mathrm{n}=19$ ). Moreover, $\mathrm{Pe}$ is different for the assimilation and the respiration processes. For example, in spring, for the glutamic acid assimilation, Pe is equal to 1.5 and 4.8 at 1000 and $2000 \mathrm{~m}$ depth, respectively; meanwhile for the corresponding respiration processes, Pe is equal to 1.8 and 1.9 .

\section{Depth integrated aminopeptidase activity and glutamic acid uptake}

Fluxes of peptides potentially released from aminopeptidase activities (Fig. 4a) were calculated from maximum velocity rates $\left(\mathrm{V}_{\max }\right)$ according to the multiconcentration kinetic method. For example in the upper water layer (10 to $200 \mathrm{~m}$ ), in spring, potential aminopeptidase activity was highest at $13.7 \mathrm{mg} \mathrm{C} \mathrm{m}^{-2} \mathrm{~h}^{-1}$. We observed that depth-integrated aminopeptidase activ-
Table 1. The ratio of undecompressed $\left(\mathrm{V}_{\mathrm{HP}}\right)$ to decompressed $\left(\mathrm{V}_{\mathrm{DEC}}\right)$ rate measurements for aminopeptidase, glutamic acid assimilation, glutamic acid respiration and glutamic acid uptake rates. nd: not done

\begin{tabular}{|cccccc|}
\hline \multirow{5}{*}{ Spring } & $\begin{array}{c}\text { Depth } \\
(\mathrm{m})\end{array}$ & $\begin{array}{c}\text { Amino- } \\
\text { peptidase }\end{array}$ & $\begin{array}{c}\text { Glutamic acid } \\
\text { assimilation }\end{array}$ & $\begin{array}{c}\text { Glutamic acid } \\
\text { respiration }\end{array}$ & $\begin{array}{c}\text { Glutamic acid } \\
\text { uptake }\end{array}$ \\
& 1000 & & 1.5 & 1.8 & 1.3 \\
& 2000 & 1.5 & 4.8 & 1.9 & 2.9 \\
Fall & 1000 & 2.8 & 2.4 & 1.2 & 1.3 \\
& 1500 & & 15.4 & 12.7 & 13.4 \\
& 2000 & & 4.3 & 7.0 & 5.2 \\
& 2000 & 2.8 & 1.8 & nd & nd \\
\hline
\end{tabular}

ity was higher in the deep-water layer than in the shallow-water layer (Fig. 4a). Conversely, depth-integrated fluxes for glutamic acid assimilation and respiration were maximal in the photic layer, with exception of the respiration flux, which was optimal in the 1000 to $2000 \mathrm{~m}$ layer in fall (Fig. 4b). Finally, depth-integrated fluxes calculated from rates measured under in situ pressure conditions were always higher than those measured by using decompressed samples (Fig. 4).

\section{DISCUSSION}

\section{Bacterial growth efficiency}

Bacterial growth efficiency (BGE) is a key parameter in studying $\mathrm{C}$ cycling in the ocean. BGE is the quantity
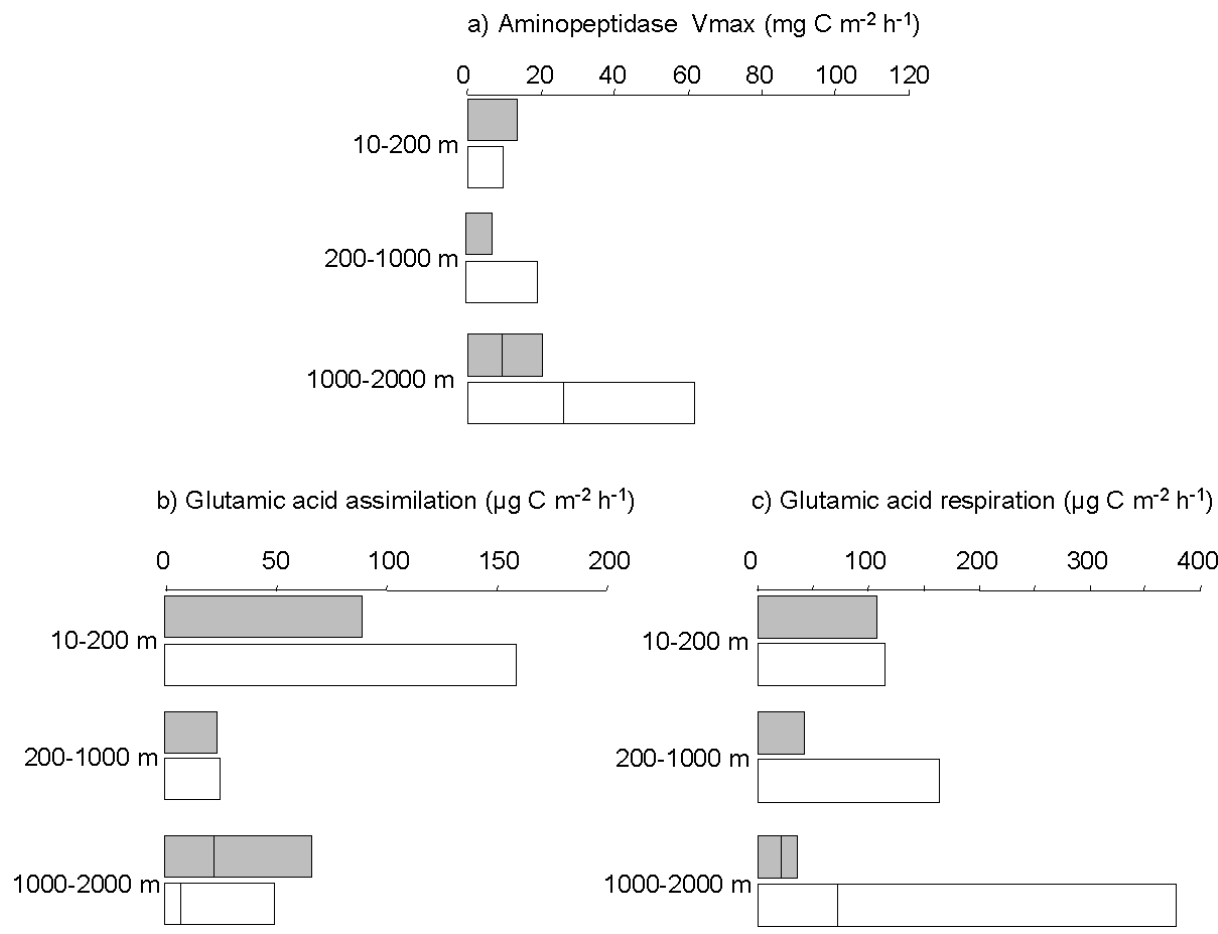

Fig. 4. Integrated aminopeptidase activity (a; EAA), glutamic acid assimilation (b; GA), and glutamic acid respiration $\left(\mathrm{C}_{i}\right.$ GR) through different water layers at the DYFAMED timeseries station: trapezoidal integration of measured rates through the upper layer (10 to $200 \mathrm{~m})$, through the mesopelagic layer (200 to $1000 \mathrm{~m}$ ) and through the bathypelagic layer (1000 to $2000 \mathrm{~m}$ ). Calculations were performed on samples collected in spring (shaded bars) and in fall (white bars). Between 1000 and $2000 \mathrm{~m}$ depth, the first part of the bar corresponds to fluxes measured under atmospheric pressure. The entire bar corresponds to fluxes measured under ambient pressure condition 
of new bacterial biomass produced per unit of organic $\mathrm{C}$ substrate assimilated. It is a way to relate bacterial production (BP) and bacterial respiration (BR): $\mathrm{BGE}=$ $\mathrm{BP} /(\mathrm{BP}+\mathrm{BR})$ (del Giorgio \& Cole 1998). Two main approaches are currently used to measure BGE: (1) concomitant measurements of BP and BR, generally measured as $\mathrm{O}_{2}$ consumption or $\mathrm{CO}_{2}$ production; (2) dilution culture in which a filter-sterilized water sample is re-inoculated with a small aliquot of its native bacterial assemblage, and then incubated in batch conditions for several days or weeks. Long-term incubation periods are required to measure significant changes in dissolved organic carbon (DOC), $\mathrm{O}_{2}$, dissolved inorganic carbon (DIC) and POC concentrations in surficial water samples (see review by del Giorgio \& Cole 1998). Unfortunately, technological difficulties make it impossible to apply these methods to deep-sea water samples. This is because: (1) in deep-sea waters, metabolic rates are slower by almost 1 order of magnitude (Bianchi et al. 1998, Tamburini et al. 2002) relative to those in the productive surficial layer. Hence, to get significant changes in DOC, $\mathrm{O}_{2}, \mathrm{DIC}$, or POC concentrations, deep-sea samples would have to be incubated for several months. During long incubation periods, wall effects could provoke changes in the microbial densities and metabolic activities. (2) Since pressure conditions affect the metabolic rates of deepsea bacterial communities (Tholosan et al. 1999, Tamburini et al. 2002), BGE assays should be made whilst maintaining the in situ pressure conditions. Unfortunately, if we are able to measure bacterial biomass production maintaining hydrostatic pressure conditions, we cannot, at present, measure $\mathrm{O}_{2}$ consumption (or $\mathrm{CO}_{2}$ production) in time-series experiments under high-pressure conditions. (3) The dilution culture approach implies that bacteria must be separated from other planktonic components by filtration. Filtration, and further sample processing, would cause serious technical difficulties if done without decompression.

To be practical, we chose to use ${ }^{14} \mathrm{C}$-glutamic acid as an example of ready-to-use low molecular weight compounds. This enabled us to measure the proportion of metabolized carbon which is incorporated into the bacterial biomass and the proportion used as an energyyielding source. Biases due to the utilization of a single radiolabeled substrate are well known. Intracellular isotope dilution and non-steady-state conditions result in a high incorporation of radiolabeled compounds into the bacterial biomass (King \& Berman 1984), which leads to underestimating $\mathrm{CO}_{2}$ production and overestimating BGE. Moreover, in natural conditions bacteria simultaneously use a large diversity of organic substrates, so extrapolation from a single model compound may lead to significant overestimation of the actual BGE (del Giorgio \& Cole 1998). Growth efficiency depends on the nature of the organic compounds added as the labeled substrate: for example, amino acids are usually incorporated more efficiently in the cell biomass than sugars (Joint \& Morris 1982).

In spite of these problems, we can directly obtain (i.e. without resorting to the use of conversion factors) the organic carbon quantity used by bacteria for energyyielding reactions and for cell anabolism. Data shown in Fig. 4b,c enabled us to calculate the ${ }^{14} \mathrm{C}$-glutamic acid assimilation yield $\left(\mathrm{GY}_{\mathrm{G}}=\mathrm{GA} / \mathrm{GU}\right)$. In spring, $\mathrm{GY}_{\mathrm{G}}$ was higher in the bathypelagic layer (52\%) than in the mesopelagic $(36 \%)$ and the euphotic layers $(45 \%)$. This enhancement of the growth yield in the deep-sea waters in spring may be associated with an exceptional supply of organic particles at depth in the DYFAMED area during this period (308 $\mathrm{mg} \mathrm{C} \mathrm{m}^{-2} \mathrm{~d}^{-1}$ measured in the sediment trap at 1000 m, J. C. Miquel pers. comm.). Rapidly sinking detritus provides fresh organic material to the deep-sea waters. During this period, the deep-sea bacteria are fuelled by labile compounds, and so limit their energy expenses. By contrast, in fall, POC fluxes are much lower, and surprisingly the particle flux at $1000 \mathrm{~m}\left(17.5 \mathrm{mg} \mathrm{C} \mathrm{m}^{-2} \mathrm{~d}^{-1}\right)$ is higher than at $200 \mathrm{~m}$ (5.3 mg C m $\mathrm{m}^{-2} \mathrm{~d}^{-1}$; J. C. Miquel pers. comm.). This could be due to a decoupling between primary production in surficial waters and the particle fluxes reaching depth. Greater fluxes in deep-sea than in shallow waters might correspond to the arrival at depth of slowly sinking particles. A longer sinking period implies that the most labile fraction of this material has been exhausted by heterotrophic bacteria during its transit through the superficial and intermediate water layers. So, in the deep-water layer, to synthesize the ectoenzymes needed to hydrolyze the less labile residual compounds, bacteria should have to spend more energy than usual. This behavior is translated into higher $\mathrm{CO}_{2}$ production (Fig. 4c). In the meantime, bacteria produce little biomass, which implies low BGE. This assumption is supported by the $\mathrm{GY}_{\mathrm{G}}$ values we found. In fall, $\mathrm{GY}_{\mathrm{G}}$ was equal to $58 \%$ in the upper layer and then decreased down to $13 \%$ between 200 and $1000 \mathrm{~m}$, and only $9 \%$ in the 1000 to $2000 \mathrm{~m}$ layer.

Data obtained using the HPSS enabled us to compare $\mathrm{GY}_{\mathrm{G}}$ obtained from assays performed under in situ pressure conditions to their counterpart concomitantly obtained from decompressed samples. This comparison provided an estimate of the adaptation of bacteria to deep-sea conditions. In spring, as well as in fall, $\mathrm{GY}_{\mathrm{G}}$ was $20 \%$ lower from decompressed samples than from assays performed under in situ pressure conditions. Indeed, these results confirm that decompression of deep-sea water samples provokes physiological stress in deep-sea bacteria. This stress induces an increase of energy-yielding processes, and so, assuming the effects of pressure would be identical on BGE and 
$\mathrm{GY}_{\mathrm{G}}$, decompression of deep-sea samples would provoke an underestimation of BGE. Such behavior differs from that observed by Turley \& Lochte (1990) during their assays to monitor the effect of hydrostatic pressure on BGE on near-bottom water samples decompressed during retrieval and then recompressed on board the research vessel. Samples recompressed at $45 \mathrm{MPa}$ showed higher mineralization rates and lower BGE than those incubated under atmospheric pressure conditions. This difference in pressure effect on BGE could be due either to the double pressure shock suffered by bacteria in decompression-recompression experiments, or to a physiological discrepancy between the bathypelagic bacterial populations we studied and the benthic populations studied by Turley \& Lochte (1990).

\section{Energy source and microbial mineralization in deep-sea waters}

Quantification of the contribution of heterotrophic bacteria to the carbon cycle in deep-sea waters is poorly documented. In deep-sea waters, microbial activity is not limited by $\mathrm{N}$ and $\mathrm{P}$ concentrations, which is not usual in the productive surface layer, so limitation is more likely to be due to the poor availability of organic carbon. In the deep sea, organic material is mainly in the dissolved form, and the molecular size of DOM decreases with increasing depth (Benner et al. 1992, Ogawa \& Ogura 1992, Fig. 5). Yet, only LMW compounds $(<600 \mathrm{Da})$ can enter directly through the cell membrane of bacteria (Nikaido \& Vaara 1985). The LMW compounds that accumulate in deep waters are the leftovers of previous bacterial attacks on the organic material produced in the upper part of the water column. These LMW residues of uncharacterized nature form the least reactive fraction of DOM (r-LMW in Fig. 5). Amon \& Benner (1996) proposed the size-reactivity continuum model, providing a framework to interpret the diagenetic alterations leading to such material. This conceptual model links the physical size of organic matter to its diagenetic state, suggesting a decrease in size with increasing diagenesis and chemical alteration. Hence, stability of the DOM concentration measured in deep-sea waters (Cauwet et al. 1997, Avril 2002, Benner 2002, Sempéré et al. 2002) might reflect its status as a residual fraction difficult to utilize. Consequently, deep-sea bacteria do not find their main nutrient source in the r-LMW DOM, but in the particulate material sinking through the water column (see Fig. 5). Therefore, deep-sea microbial growth may be highly dependent on the quantity and quality of the sinking particles. Indeed, in spring we observed that high fluxes of relatively fresh POC pro- duced high $\mathrm{GY}_{\mathrm{G}}(65 \%)$ and a low depth-integrated potential ectoaminopeptidase (EAA) $\left(2305 \mathrm{\mu g} \mathrm{C} \mathrm{m}^{-2} \mathrm{~h}^{-1}\right)$. Meanwhile in fall, a low flux of relatively old organic matter leads to higher potential depth-integrated EAA (62 $163 \mu \mathrm{g} \mathrm{C} \mathrm{m}^{-2} \mathrm{~h}^{-1}$ ) and lower $\mathrm{GY}_{\mathrm{G}}(12 \%)$. Such activities make the semi-labile fraction that escaped microbial degradation during its descent through the water column accessible to deep-sea bacteria. During mesotrophic conditions (i.e. in spring), we observed a tight coupling between the flow of sinking particles and bacterial metabolism. Indeed, sinking particles show a loss of carbon between 200 and $1000 \mathrm{~m}^{-1} 200 \mathrm{mg} \mathrm{C} \mathrm{m}^{-2}$ $\mathrm{d}^{-1}$ (sediment trap gave $528 \mathrm{mg} \mathrm{m}^{-2} \mathrm{~d}^{-1}$ at $200 \mathrm{~m}$, and $308 \mathrm{mg} \mathrm{m}^{-2} \mathrm{~d}^{-1}$ at $1000 \mathrm{~m}$ ). During the same period, assuming a growth yield of $10 \%$, and a bacterial biomass production of $14 \mathrm{mgC} \mathrm{m}^{-2} \mathrm{~d}^{-1}$ (calculated from Tamburini et al. 2002) bacterial carbon demand is equal to $137 \mathrm{mgC} \mathrm{m}^{-2} \mathrm{~d}^{-1}$ and aminopeptidase activities release $169 \mathrm{mg} \mathrm{C} \mathrm{m}^{-2} \mathrm{~d}^{-1}$ (Fig. 4). In contrast, during oligotrophic conditions (i.e. in fall), the particle flux is very low showing a decoupling between the trap at $200 \mathrm{~m}$ depth and that at $1000 \mathrm{~m}$ (5.3 and $17.5 \mathrm{mgC} \mathrm{m}^{-2} \mathrm{~d}^{-1}$, respectively, J. C. Miquel pers. comm.). Such a decoupling implies that bacteria must find carbon and energy from a source other than the POM. In this case, deep-sea bacteria over-express their ectoenzymatic system, which is costly in energy, to extract carbon and energy sources necessary for their metabolism from the bulk DOM.

From these observations and those cited in the literature, we can discuss the relationships between the nutritive sources available for deep-sea bacteria, the role of these organisms in the mineralization of peptide compounds, and consequently their implication for the global carbon cycle. During their descent to the bottom, particles release DOC by abiotic processes (Karl et al. 1988) and by enzymatic hydrolysis of biopolymers processed by the attached bacteria (Cho \& Azam 1988, Kiørboe \& Jackson 2001). The released monomers fuel the production of free-living bacteria biomass in the mesopelagic zone (Cho \& Azam 1988, Smith et al. 1992). This POC $\rightarrow$ DOC $\rightarrow$ bacteria link occurs within the bathypelagic environment (Nagata et al. 2000, Tanaka \& Rassoulzadegan 2002, the present study in spring). The response of bacteria to the DOM streaming behind sinking particles of marine snow may have a major influence on the oceanic carbon cycle (Azam \& Long 2001, Kiørboe \& Jackson 2001). Kiørboe \& Jackson (2001) model the formation of this plume. They predict that free-living bacteria can take advantage of the plume and use it to fuel a population explosion. Despite occupying only a small fraction of the ocean's volume, the plumes may provide important growth habitats for free-living bacteria and account for a significant proportion of bacterial pro- 


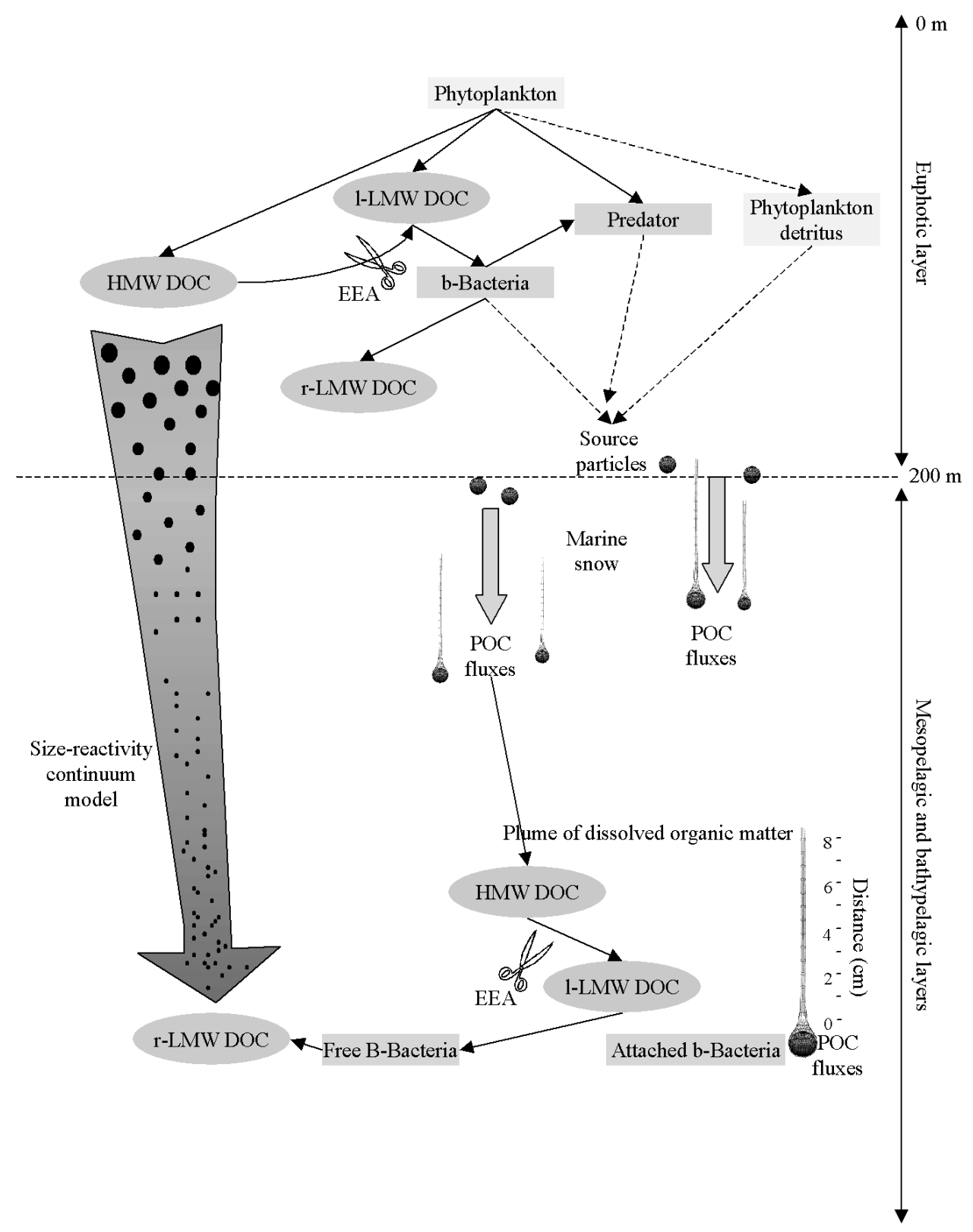

Fig. 5. Participation of microorganisms in the mineralization processes. This interpretation compares the sources of organic matter available for bacteria in the euphotic layer and in the mesopelagic and bathypelagic layers. It relies on the relationship with the size-reactivity continuum model for organic matter decomposition in deep-sea waters (Amon \& Benner 1996), and integrates the concept of microbial activity enhancement in the plume following the fall of an organic particle through the water column. The plume is formed by enzymatic dissolution of colonizing bacteria (Kiørboe \& Jackson 2001). The marine snow and the plume may become the focus of a complex food web (Azam \& Long 2001). HMW DOC: high molecular weight dissolved organic carbon; l-LMW DOC: labile low molecular weight DOC; r-LMW DOC: refractory LMW DOC; B-Bacteria: bacteria adapted to high hydrostatic pressure; b-Bacteria: bacteria unadapted to high hydrostatic pressure conditions

duction throughout the mesopelagic and bathypelagic water masses (Fig. 5). Some of our preliminary assays to simulate the descent of diatoms through the water column demonstrated that enzymatic hydrolysis rates performed by attached bacteria were affected by increasing pressure as and when particles descend
(Tamburini 2002). This behavior shows the importance of maintaining in situ conditions for free-living bacteria, and for those attached to sinking particles that constitute the main source of organic inputs to the deep sea, when evaluating the role of deep-sea bacteria in the mineralization of organic matter. 
Acknowledgements. This work was partially funded by the Institut National des Sciences de l'Univers (Programme Flux Océaniques DYFAMED) and Total-Fina-Elf (grant no. 11997 - CNRS/ENTREPRISE). C.T. was supported by a fellowship co-funded by INSU and Total-Fina-Elf. The authors are very grateful for the critical comments on the draft provided by F. Van Wambeke and D. Kirchman, the improving of the English by T. Bentley, and to J. C. Miquel for providing data on POC flow. We thank the captains and crews of RV 'Tethys II' for cruise assistance.

\section{LITERATURE CITED}

Amon RMW, Benner R (1996) Bacterial utilisation of different size classes of dissolved organic matter. Limnol Oceanogr 41:41-51

Amon RMW, Fitznar HP, Benner R (2001) Linkages among the bioreactivity, chemical composition, and diagenetic state of marine dissolved organic matter. Limnol Oceanogr 46: 287-297

Andersen V, Prieur L (2000) One-month study in the open NW Mediterranean Sea (DYNAPROC experiment, May 1995): overview of the hydrobiogeochemical structures and effects of wind events. Deep-Sea Res I 47:397-422

Avril BU (2002) DOC dynamics in the northwestern Mediterranean Sea (DYFAMED site). Deep-Sea Res II 49: $2163-2182$

Azam F, Long RA (2001) Sea snow microcosms. Nature 414: 495-498

Benner R (2002) Chemical composition and reactivity. In: Hansell DA, Carlson CA (eds) Biogeochemistry of marine dissolved organic matter. Academic Press, San Diego, p 59-90

Benner R, Pakulski JD, McCarthy M, Hedges JI, Hatcher PG (1992) Bulk chemical characteristics of dissolved organic matter in the ocean. Science 25:1561-1564

Béthoux JP, Prieur L, Bong JH (1988) Le courant Ligure au large de Nice. In: Minas JH, Nival P (eds) Océanographie pélagique méditerranéenne. Oceanol Acta No SP 9:59-67

Bianchi A, Garcin J (1993) In stratified waters the metabolic rate of deep-sea bacteria decreases with decompression. Deep-Sea Res I 40:1703-1710

Bianchi A, Garcin J (1994) Bacterial response to hydrostatic pressure in seawater samples collected in mixed-water and stratified-water conditions. Mar Ecol Prog Ser 111: 137-141

Bianchi A, Van Wambeke F, Garcin J (1998) Bacterial utilization of glucose in the water column from eutrophic to oligotrophic pelagic areas in the eastern North Atlantic Ocean. J Mar Systems 14:45-55

Bianchi A, Garcin J, Tholosan O (1999) A high-pressure serial sampler to measure microbial activity in the deep sea. Deep-Sea Res I 46:2129-2142

Cauwet G, Miller A, Brasse S, Fengler G, Mantoura RFC, Spitzy A (1997) Dissolved and particulate organic carbon in the western Mediterranean Sea. Deep-Sea Res II 44: $769-779$

Cho BC, Azam F (1988) Major role of bacteria in biogeochemichal fluxes in the ocean's interior. Nature 332: 441-443

Chrost RJ (1991) Environmental control of the synthesis and activity of aquatic microbial ectoenzymes. In: Chrost RJ (ed) Microbial enzymes in aquatic environments. Springer-Verlag, New York, p 29-59

Chrost RJ, Velimirov B (1991) Measurement of enzyme kinetics in water samples: effect of freezing and soluble stabilizer. Mar Ecol Prog Ser 70:93-100

del Giorgio PA, Cole JJ (1998) Bacterial growth efficiency in natural aquatic ecosystems. Annu Rev Ecol Syst 29: 503-541

del Giorgio PA, Cole JJ, Cimbleris A (1997) Respiration rates in bacteria exceed phytoplankton production in unproductive aquatic systems. Nature 385:148-151

Deming JW, Tabor PS, Colwell RR (1980) Deep ocean microbiology. In: Diemer F, Vernberg J, Mirkes D (eds) Advanced concepts in ocean measurements for marine biology. University of South Carolina Press, Columbia, p 285-305

Ducklow HW, Carlson CA (1992) Oceanic Bacterial Production. In: Marshall (ed) Advances in microbial ecology, Vol 12. Plenum Press, New York, p 113-181

Hoppe H-G (1993) Use of fluorogenic model substrates for extracellular enzyme activity measurement of bacteria. In: Kemp PF, Sherr BF, Sherr E B, Cole JJ (eds) Handbook of methods in aquatic microbial ecology. Lewis Publishers, Boca Raton, FL, p 423-431

Jaenicke R (1987) Cellular components under extremes of pressure and temperature: structure-function relationship of enzymes under pressure. In: Jannasch HW, Marquis RE, Zimmerman AM (eds) Current perspective in high pressure biology. Academic Press, London, p 257-272

Joint IR, Morris RJ (1982) The role of bacteria in the turnover of organic matter in the sea. Oceanogr Mar Biol Annu Rev 20:65-118

Karl DM, Knauer GA, Martin JH (1988) Downward flux of particulate organic matter in the ocean: a particle decomposition paradox. Nature 332:438-440

King GM, Berman T (1984) Potential effects of isotopic dilution on apparent respiration in ${ }^{14} \mathrm{C}$ heterotrophic experiments. Mar Ecol Prog Ser 19:175-180

Kiørboe T, Jackson GA (2001) Marine snow, organic solute plumes, and optimal chemosensory behavior of bacteria. Limnol Oceanogr 46:1309-1318

Lamy F, Bianchi M, Van Wambeke F, Sempéré R, Talbot V (1999) Use of data assimilation techniques to analyze the significance of ectoproteolytic activity measurements performed with the model substrate MCA-Leu. Mar Ecol Prog Ser 177:27-35

Lee C, Wakeham SG, Hedges JI (2000) Composition and flux of particulate amino acids and chloropigments in equatorial Pacific seawater and sediments. Deep-Sea Res I 47: $1535-1568$

Lefèvre D, Denis M, Lambert CE, Miquel J-C (1996) Is DOC the main source of organic matter remineralization in the ocean water column? J Mar Systems 201:281-291

Marty JC, Chiaverini J, Pizay MD, Avril B (2002) Seasonal and interannual dynamics of nutrients and phytoplankton pigments in the western Mediterranean Sea at the DYFAMED time-series station (1991-1999). Deep-Sea Res II 49: 1965-1985

McCarthy M, Hedges J, Benner R (1996) Major biochemical composition of dissolved high molecular weight organic matter in seawater. Mar Chem 55:281-297

Nagata T, Fukuda H, Fukuda R, Koike I (2000) Bacterioplankton distribution and production in deep Pacific waters: large-scale geographic variations and possible coupling with sinking particle fluxes. Limnol Oceanogr 45:426

Nikaido H, Vaara M (1985) Molecular basis of bacterial outer membrane permeability. Microbiol Rev 49:1-32

Ogawa H, Ogura N (1992) Comparison of two methods for measuring dissolved organic carbon in sea water. Nature 356:696-698

Poremba K (1994) Impact of pressure on bacterial activity in 
water columns situated at the european continental margin. Neth J Sea Res 33:29-35

Sempéré R, Panagiotopoulos C, Lafont R, Marroni B, Van Wambeke $F$ (2002) Total organic carbon dynamics in the Aegean Sea. J Mar Systems 33-34:355-364

Smith DC, Simon M, Alldredge AL, Azam F (1992) Intense hydrolytic enzyme activity on marine aggregates and implications for rapid particle dissolution. Nature 359: 139-142

Straube WL, O'Brien M, Davis K, Colwell RR (1990) Enzymatic profiles of 11 barophilic bacteria under in situ conditions: evidence for pressure modulation of phenotype. Appl Environ Microbiol 56:812-4

Tabor PS, Deming JW, Ohwada K, Davis H, Waxman M, Colwell RR (1981) A pressure-retaining deep ocean sampler and transfer system for measurement of microbial activity in the deep sea. Microb Ecol 7:51-65

Tamburini C (2002) La dégradation du matériel organique profond par les microflores profondes: de la mesure des vitesses potentielles au flux de $\mathrm{CO}_{2}$ généré in situ. $\mathrm{PhD}$ thesis, Université de la Méditerranée, Marseille

Editorial responsibility: David Karl,

Honolulu, Hawaii, USA
Tamburini C, Garcin J, Ragot M, Bianchi A (2002) Biopolymer hydrolysis and bacterial production under ambient hydrostatic pressure through a $2000 \mathrm{~m}$ water column in the NW Mediterranean. Deep-Sea Res II 49:2109-2123

Tanaka T, Rassoulzadegan F (2002) Full-depth profile $(0-2000 \mathrm{~m})$ of bacteria, heterotrophic nanoflagellates and ciliates in the NW Mediterranean Sea: vertical partitioning of microbial trophic structures. Deep-Sea Res II 49: 2093-2107

Tholosan O, Garcin J, Bianchi A (1999) Effects of hydrostatic pressure on microbial activity through a $2000 \mathrm{~m}$ deep water column in the NW Mediterranean Sea. Mar Ecol Prog Ser 183:49-57

Turley C, Lochte K (1990) Microbial response to the input of fresh detritus to the deep-sea bed. Palaeogeogr Palaeoclimatol Palaeoecol 89:3-23

Yayanos AA (1995) Microbiology to 10500 meters in the deep sea. Annu Rev Microbiol 49:777-805

ZoBell CE, Oppenheimer CH (1950) Some effects of hydrostatic pressure on the multiplication and morphology of marine bacteria. J Bacteriol 60:771-781

Submitted: July 23, 2002; Accepted: March 4, 2003

Proofs received from author(s): June 11, 2003 